\title{
Knowledge and attitude of teenagers regarding traffic safety rules
}

\author{
Amala Shaji ${ }^{1}$, Amrutha PP², Tessy Joseph ${ }^{3}$, Safa S ${ }^{4}$, Hezil Reema Barboza ${ }^{5^{*}}$ \\ ${ }^{1-4}$ Student, ${ }^{5}$ Lecturer, Yenepoya Nursing College, Mangalore, Karnataka, India \\ *Corresponding Author: Hezil Reema Barboza \\ Email: hezilreemabarboza@gmail.com
}

\begin{abstract}
Introduction: Road traffic accidents are the leading issues in health care sector. Every day thousands of people die and many will be left with physical disabilities which makes their family life more miserable. Road traffic accidents are commonly seen in teenagers and young adults. This study was conducted to understand the level of knowledge of teenagers on traffic safety rules and their attitude about it.

Materials and Methods: A descriptive design was adopted for the study. The data was collected using structured knowledge questionnaire to understand the knowledge on regulations of traffic safety and attitude was measured using rating scale. The validity of the domains of questionnaire and rating scale was established in consultation with six experts. Reliability of the knowledge questionnaire was tested by using spilt half method and attitude scale by Cronbach's alpha. Pretesting of tool and pilot study was conducted among 10 samples.

Results: The study results showed $80 \%$ students had average knowledge on traffic safety rules and had a favorable attitude towards traffic safety rules. There was a significant association between level of knowledge and demographic variables such as such age $\left(\chi^{2}=0.044\right)$, and information regarding traffic safety rules $\left(\chi^{2}=0.043\right)$. There was a significant association between attitude and source of information regarding road safety rules $\left(\chi^{2}=0.018\right)$

Conclusion: The finding of the study revealed that majority of the teenagers had average knowledge and had favorable attitude towards traffic safety rules.
\end{abstract}

Keywords: Attitude, Driving license, Knowledge, Traffic safety accidents, Traffic safety rules.

\section{Introduction}

Traffic rules are the laws which regulate the vehicles to prevent road traffic accidents. Every country have formulated different traffic rules and regulations. ${ }^{1}$ Traffic signs give information about the road conditions ahead, provide instructions to be followed at the major crossroads to warn or guide drivers and ensure proper functioning of road traffic. ${ }^{2}$ WHO statistics reported that 1.24 million people lost their life and over 50 million were injured due to motor vehicle accident in 2010. Males younger than 25 years accounted for $73 \%$ of deaths due to traffic accidents. ${ }^{3}$ The risk of motor vehicle crashes is higher among 16-19 year-old than among any other age group. ${ }^{4}$ The factors contribute to road accidents are over speeding, violation of rules, failure to understand signs, alcohol, crossing at wrong places, catching a running bus, damaged roads, illegal speed breakers, and weather conditions etc. ${ }^{5}$

National Crime Records Bureau (NCRB) reported about 135,000 deaths occurs in India every year due to traffic collusion. ${ }^{6}$ The NGO 'Indians for Road Safety' reported that in 2015, every single person died in every 4 mins in India. ${ }^{7}$ The "Global Status Report on Road Safety" which was published by the World Health Organization (WHO) identified the very important and common causes of traffic collusions as driving over the speed limit, driving under the influence,driving without helmets, and not using seat belts during driving. ${ }^{8}$

\section{Objectives}

The objectives of the study were:

1. to understand the level of knowledge of teenagers regarding traffic safety rules

2. to assess the attitude regarding traffic safety rules
4. to find the association between the knowledge score and selected demographic variables

5. to find the association between the attitude score and selected demographic variables

\section{Materials and Methods}

The Quantitative research approach with non-experimental descriptive design was selected for the study. Due to the availability of samples sampling techniques used to select the sample was convenient sampling technique. Based on the literature on the relevant topic tools were developed. Six experts from different fields such as Community Medicine, Master of Social Work, Community Health Nursing, Medical Surgical Nursing, and Child Health Nursing validated the tools. The reliability co-efficient of the structured knowledge questionnaire was calculated using spilt half method and attitude scale by using Cronbach's alpha. The reliability of the tool was found to be $\mathrm{r}(10)=0.8$ respectively for both the tools which was statistically significant. The tools were found to be reliable. A small scale study was conducted to find the feasibility of the study. The data were collected from 100 teenagers by using demographic proforma, structured knowledge questionnaire and attitude scale. The demographic variables included were age, gender, educational status, availing driving license, injury during driving, previous information regarding traffic safety rules and source of information. Analysis of collected data was performed by using SPSS.

\section{Results}

Section 1: Demographic data of samples

3. 
Table 1: Frequency and percentage distribution of samples

\begin{tabular}{|c|c|c|c|}
\hline S. No. & Demographic variables & Frequency (f) & Percentage (\%) \\
\hline 1. & $\begin{array}{l}\text { Age in years } \\
\text { a) } 18 \text { years } \\
\text { b) } 19 \text { years } \\
\text { c) } 20 \text { years }\end{array}$ & $\begin{array}{c}30 \\
66 \\
4 \\
\end{array}$ & $\begin{array}{c}30 \\
66 \\
4 \\
\end{array}$ \\
\hline 2. & $\begin{array}{l}\text { Gender } \\
\text { a)Male } \\
\text { b)Female }\end{array}$ & $\begin{array}{c}100 \\
0\end{array}$ & $\begin{array}{c}100 \\
0\end{array}$ \\
\hline 3. & $\begin{array}{l}\text { Educational status } \\
\text { a)First year } \\
\text { b)Second year } \\
\text { c)Third year }\end{array}$ & $\begin{array}{c}32 \\
64 \\
4\end{array}$ & $\begin{array}{l}32 \\
64\end{array}$ \\
\hline 4. & $\begin{array}{l}\text { Do you have driving license } \\
\text { a)Yes } \\
\text { b)No }\end{array}$ & $\begin{array}{l}86 \\
14\end{array}$ & $\begin{array}{l}86 \\
14\end{array}$ \\
\hline 5. & $\begin{array}{l}\text { Have you ever been injured during driving } \\
\text { a)Yes } \\
\text { b)No }\end{array}$ & $\begin{array}{l}70 \\
30\end{array}$ & $\begin{array}{l}70 \\
30\end{array}$ \\
\hline 6. & $\begin{array}{l}\text { Do you know any information regarding traffic safety } \\
\text { rules? } \\
\text { a)Yes } \\
\text { b)No }\end{array}$ & $\begin{array}{c}99 \\
1 \\
\end{array}$ & $\begin{array}{c}99 \\
1 \\
\end{array}$ \\
\hline 7. & $\begin{array}{l}\text { Information regarding road safety rules obtained from } \\
\text { a)Mass media } \\
\text { b)Books } \\
\text { c)Lecture classes } \\
\text { d)Others-specify }\end{array}$ & $\begin{array}{c}59 \\
33 \\
8 \\
0\end{array}$ & $\begin{array}{c}59 \\
33 \\
8 \\
0\end{array}$ \\
\hline
\end{tabular}

Section 2: Description of samples according to knowledge on Traffic Safety Rules

Table 2: Frequency and percentage distribution based on knowledge score $n=100$

\begin{tabular}{|c|c|c|}
\hline Level of knowledge & Knowledge score & Percentage[\%] \\
\hline Poor & $0-10$ & 1 \\
Average & $11-20$ & 80 \\
Good & Above 20 & 19 \\
\hline
\end{tabular}

Table 3: Mean, mean $\%$, standard deviation, median of knowledge score

\begin{tabular}{|c|c|c|c|}
\hline Mean & Mean\% & Standard Deviation & Median \\
\hline 17.97 & 64.17 & 2.893 & 18 \\
\hline
\end{tabular}

Section 3: Description of samples according to their level of attitude on traffic safety rules

Table 4: Description of subject according to the level of attitude on traffic safety rules $n=100$

\begin{tabular}{|l|c|c|}
\hline Category & Score & Percentage[\%] \\
\hline Favorable attitude & $21-40$ & $91 \%$ \\
\hline Unfavorable attitude & $1-20$ & $9 \%$ \\
\hline
\end{tabular}

Table 5: Mean, mean\%, standard deviation median of attitude score

\begin{tabular}{|c|c|c|c|}
\hline Mean & Mean\% & Standard Deviation & Median \\
\hline 25.81 & 64.53 & 4.02 & 26 \\
\hline
\end{tabular}

Section 4: Association between knowledge score with selected demographical variables

To find the association between knowledge score and selected demographic variables, the null hypothesis was stated and it was tested by using chi-square test. 
Table 6: Association between knowledge score and selected demographic variables $n=100$

\begin{tabular}{|c|c|c|}
\hline S. No & Demographic variables & Chi-square valuc \\
\hline 1 & $\begin{array}{l}\text { Age } \\
\text { a. } 18 \text { years } \\
\text { b. } 19 \text { years } \\
\text { c. } 20 \text { years }\end{array}$ & $0.044 *$ \\
\hline 2 & $\begin{array}{l}\text { Gender } \\
\text { a.Male } \\
\text { b. Female }\end{array}$ & 100 (constant) \\
\hline 3 & $\begin{array}{l}\text { Educational status } \\
\text { a.First year degree } \\
\text { b.Second year degree } \\
\text { c.Third year degree } \\
\end{array}$ & 0.056 \\
\hline 4 & $\begin{array}{l}\text { Do you have driving license } \\
\text { a.Yes } \\
\text { b. No }\end{array}$ & 0.357 \\
\hline 5 & $\begin{array}{l}\text { Have you ever been injured during driving } \\
\text { a.Yes } \\
\text { b. No }\end{array}$ & 0.693 \\
\hline 6 & $\begin{array}{l}\text { Do you know any information regarding safety rules } \\
\text { a.Yes } \\
\text { b. No }\end{array}$ & $0.043 *$ \\
\hline 7 & $\begin{array}{l}\text { Information regarding road safety rules obtained from } \\
\text { a.Mass media } \\
\text { b.Books } \\
\text { c.Lecturer classes } \\
\text { d.Others-specify }\end{array}$ & 0.144 \\
\hline
\end{tabular}

* Significance, table value $=0.05$

The data presented in the table 6 shows that there was a significant association between knowledge score and demographical variable such as age $\left(\chi^{2}=0.044\right)$, information regarding traffic safety rules $\left(\chi^{2}=0.043\right)$ and there was no association with the other variables.

Table 7: Association between level of attitude and selected demographic variables $n=100$

\begin{tabular}{|l|l|c|}
\hline S. No & Demographic variables & Chi-square \\
\hline 1. & $\begin{array}{l}\text { Age } \\
\text { a. } 18 \text { years } \\
\text { b. } 19 \text { years } \\
\text { c. } 20 \text { years }\end{array}$ & 0.720 \\
\hline 2. & $\begin{array}{l}\text { Gender } \\
\text { a. Male } \\
\text { b. Female }\end{array}$ & 100 (constant) \\
\hline 3. & $\begin{array}{l}\text { Educational status } \\
\text { a. First year } \\
\text { b. Second year } \\
\text { c. Third year }\end{array}$ & \\
\hline $\begin{array}{l}\text { Do you have driving license? } \\
\text { a. Yes } \\
\text { b. No }\end{array}$ & $\begin{array}{l} \\
\text { Have you ever been injured during driving? } \\
\text { a. Yes } \\
\text { b. No }\end{array}$ & 0.814 \\
\hline 5. & $\begin{array}{l}\text { Do you know any information regarding traffic safety rules } \\
\text { a. Yes } \\
\text { b. No }\end{array}$ & 0.417 \\
\hline 6. & $\begin{array}{l}\text { Information regarding road safety rules obtained from } \\
\text { a. Mass media } \\
\text { b. book } \\
\text { c. Lecture classes } \\
\text { d. Other-specify }\end{array}$ & 0.240 \\
\hline 8. & \\
\hline
\end{tabular}

$*$ significance, table value $=0.05$ 
Data presented in table 7 shows that there was significant association between level of attitude and selected demographic variable such as source of information regarding road safety rules $\left(\chi^{2}=0.018\right)$ and there was no association with the other demographic variables

\section{Discussion}

In the present study result revealed that majority of the students $(66 \%)$ were in the age group of 19 years and $30 \%$ were in the age group of 18 years and $4 \%$ students were 20 years old, $86 \%$ had driving license, and $70 \%$ had injury during driving. Majority of samples $(80 \%)$ had average knowledge and $19 \%$ of them had poor and remaining $1 \%$ had good knowledge on traffic safety rules. This study was supported by the study conducted by Ali Hassan Alzahrani at Taif University, who reported the about $90 \%$ students had knowledge of road traffic regulations and $85 \%$ were aware about the importance of seat belts. The students were belonged to age 21 years and all had driving license. More than $50 \%$ were injured due to accident. ${ }^{9}$

Another study was conducted to determine the knowledge, attitudes and practice concerning road traffic accident among 109 university students in Malaysia. The study results revealed participants had moderate knowledge about road traffic regulations. About 39 (35.7\%) students were injured in road traffic accident. About $93.6 \%$ of them were aware about the use of seat belts. Age and attitude were significantly associated with the exposure to the accident. $^{10}$

There was a significant association between level of knowledge and demographic variables such as such as age $\left(\chi^{2}=0.044\right)$, and information regarding traffic safety rules $\left(\chi^{2}=0.043\right)$. There was a significant association between attitude and information regarding road safety rules $\left(\chi^{2}=\right.$ $0.018)$.

\section{Conclusion}

The study concludes that majority of teenagers $(80 \%)$ had average knowledge on traffic safety rules and $91 \%$ had favorable attitude towards traffic safety rules. The present study data suggest that the need to enforce strict traffic regulations for improving the use of helmet and seat belts during driving. Enforcement of effective traffic law, regular awareness programs on traffic safety rules, ensuring good vehicle and road condition will be helpful to reduce the risk of motor vehicle accidents India.

\section{Conflict of Interest: None.}

\section{References}

1. Traffic signs and rules in India. Available from https://www.bankbazaar.com/driving-licence/traffic-signs-andrules.html

2. Traffic safety. Available: http://www.ecards4ever.com/quotations/traffic-safety.php

3. Motor vehicle safety. Available from https://www.cdc.gov/motorvehiclesafety/teen_drivers/teendrivers _factsheet.html
4. Rolison JJ, Regev S, Moutari S, Feeney A. What are the factors that contribute to road accidents? An assessment of law enforcement views, ordinary drivers' opinions, and road accident records. Accident Anal Prev 2018;115:11-24.

5. Traffic collisions in India. Available: https://en.wikipedia.org/wiki/Traffic_collisions_in_India

6. Crime in India 2016. Available from http://ncrb.gov.in/StatPublications/CII/CII2016/pdfs/NEWPDFs/ Crime\%20in\%20India\%20-

\%202016\%20Complete\%20PDF\%20291117.pdf

7. National Crime Bureau (NCRB). Available from https://data.gov.in/ministrydepartment/national-crime-recordsbureau-ncrb?page $=20$

8. Global status report road safety 2018. Available from https://www.who.int/violence_injury_prevention/road_safety_stat us/2018/GSRRS2018_Summary_EN.pdf

9. AlZahrani A, Ahmed E. Knowledge and attitude toward road traffic regulations among students of Health Sciences College in Taif Region, KSA. Int J Med Sci Public Health 2014;4(2):241-4.

10. Redhwan AA, Karim AJ. Knowledge, attitude and practice towards road traffic regulations among university students, Malaysia. Int Med J Malaysia 2010;9(2):29-34.

How to cite this article: Shaji A, Amrutha PP, Joseph T, Safa S, Barboza HR. Knowledge and attitude of teenagers regarding traffic safety rules. Int $J$ Med Paediatr Oncol 2019;5(2):54-7. 